\title{
Antecedents of Entrepreneurial Processes of Causation and Opportunity Recognition in Building Material Retail Trade in Nigeria
}

Adamu Ado Makama

Putra Business School, Universiti Putra Malaysia

Mohani B, Abdul

Faculty of Economics and Management, Universiti Putra Malaysia

Murali Sambasivan

Taylor's Business School, Taylor's University Subang Jaya, Malaysia

\section{Raja Nerina Raja Yusof}

Faculty of Economics and Management, Universiti Putra Malaysia Corresponding author; Email: makama_ado@yahoo.com

\section{Doi:10.5901/mjss.2016.v7n3p66}

\section{Abstract}

Entrepreneurial opportunity has been a highly contentious construct among entrepreneurial scholars. Some argue that opportunity is objective - it exists independent of entrepreneurs and it can be exploited through the causation process (consistent with opportunity as discovery) which is based on rational decision model. Some argue that opportunity cannot exist independent of entrepreneurs. The basic objective of this study is to conduct a quantitative study to examine the antecedents of causation and study the impact of causation on opportunity recognition. The antecedents examined in this study are: entrepreneur's education, entrepreneur's special education, entrepreneur's personality traits, and entrepreneur's management skills. The population for this study was Nigerian entrepreneurs dealing in building materials. A questionnaire was designed and sent to 1,950 Entrepreneurs in the Building Material Industry Trade. Results of the study indicate that (1) the antecedents influence causation process and (2) causation process influences entrepreneur's ability to recognize opportunities.

Keywords: causation; antecedents; opportunity recognition; Nigeria.

\section{Introduction}

Entrepreneurial opportunity has been studied from two opposing theoretical perspectives. The first and older perspective is unique to American scholars. This view argues that opportunity (1) is objective, (2) exists independent of the entrepreneur, and (3) is formed by exogenous shock in an existing market - an opportunity is discovered or recognised in the existing industry (Alvarez \& Barney, 2010). Study of entrepreneurial opportunity recognition is well explored and matured and is based on well-articulated theory. Lately the validity of this theory to the study of a complex phenomenon like entrepreneurship is questioned by scholars (Chandler, DeTienne, McKelvie, \& Mumford, 2011; Alvarez \& Barney, 2010; Alvarez \& Barney, 2007; Sarasvathy, 2001). New theories have been developed to explain the underlying behaviours of entrepreneurs and these theories are called 'emerging theoretical perspective'(Eisenhardt, Kotha, Meyer, \& Rajagopalan, 2010). Among the numerous emerging theoretical perspectives, Sarasvathy's (2001) causation and effectuation are widely cited in the literature. Sarasvathy (2001) calls the traditional approach to the study of entrepreneurial opportunity recognition as a 'causation' process and contrasts it with the new entrepreneurial process of opportunity creation called 'effectuation'. Chandler et al. (2011) have measured and validated causation and effectuation constructs. Consequently, previous studies are qualitative, conceptual and experimental. To date the antecedents of causation remains unexplored (Harms \& Schiele, 2012). The main objective of this study is (1) to explore factors that can predict the causation process and (2) examine the influence of entrepreneurial causation process on opportunity recognition process. 


\section{Some Prefatory Remarks on Causation and Opportunity Recognition}

Sarasvathy (2001), "causation processes take a particular effect as given and focus on selecting between means to create that effect. Effectuation processes take a set of means as given and focus on selecting between possible effects that can be created with that set of means" (p.245). The theoretical foundation for causation processes has been derived from the rational decision-making perspectives of neo-classical microeconomics (Stigler, 1952). Causal reasoning is useful in domains where the future is predictable and goals are known. Most existing entrepreneurship literature has theoretical foundation in the causation approach (Perry, Chandler, \& Markova, 2012). Causation is built on the assumption: "To the extent we can predict the future, we can control it" (Sarasvathy, 2001, p.251). Primary focus of entrepreneurship schools is within the field of causation, where theories are used to predict the future.

Classical school defines entrepreneurs as those who discover or recognise opportunities. The classical school of thought is referred to as the traditional model of entrepreneurship. It is based on neoclassical economic theories (Perry et al., 2012) which assume that individuals engage in rational goal-driven behaviours when pursuing entrepreneurial opportunity (Bird, 1989). "Entrepreneurial causation is consistent with plan strategy approach including such activities as opportunity recognition and business plan development" (Chandler et al., 2011: p. 375). In a causation process, an individual makes a decision about the information and estimates expected utility for each option (Fisher, 2012). A large part of the extant entrepreneurship literature has foundations in the causation approach. Opportunity recognition results from rational search process in which alternatives are identified and analysed (Fiet, 2002).

\section{Motivation to Study}

Numerous scholars have argued that causation process is consistent with opportunity recognition (Sarasvathy, 2001; Chandler et al., 2011; Fisher, 2012). Within the entrepreneurial opportunity recognition literature, antecedents of opportunity recognition have covered quite a number of factors. Entrepreneurial causation process is argued to influence opportunity recognition process. However, previous studies have not explored the antecedents of entrepreneurial causation process. This is not surprising since the measure for causation was provided, five years ago, by Chandler et al., (2011). Pfeffer (1993) has pointed out that paradigm shifts are slower in fields where there is less consensus regarding accepted paradigms, theories, and models. The research cycle is slower in the social sciences than in the physical sciences (Perry et al., 2012).

The contributions of this study are threefold. First, this research has eclectically combined the great person and the psychological schools of thoughts into a single construct 'Personality Traits' as presented by Cunningham and Lischeron (1991). The great person and psychological schools of thoughts define entrepreneurial behaviour through the assessment of personal qualities. These two schools of thoughts are merged into a single construct (Personal traits) and are proposed to predict causation. Second, the management and leadership schools define entrepreneurs as those who act and manage and therefore, set to possess 'Management skills' (Sambasivan, Abdul, \& Yusop, 2009, p.799). The management and leadership schools are proposed to influence entrepreneurs' decision on whether to engage in causation process. Thirdly, this study is conducted in an African setting. Most of the entrepreneurial studies so far have been conducted in Western countries (Lau, Can, \& Ho, 2004; Zhao \& Aram, 1995; Lin, 1998) and our study will be among the first few to be conducted in Nigeria exploring the antecedences of causation. Previous study on antecedents of causation was conducted on a smaller sample of 65 companies in Germany (Harms \& Schiele, 2012). The framework used in this study is presented in Figure 1.1. 


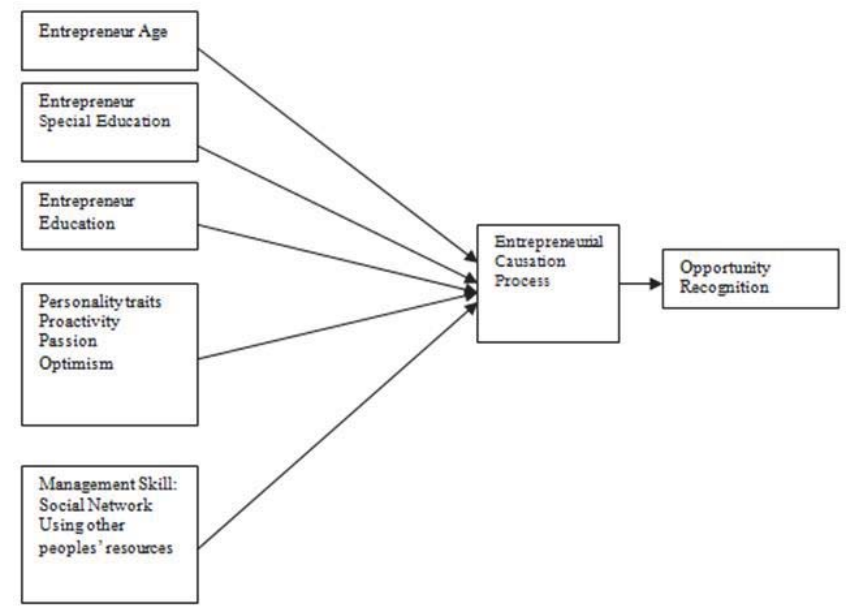

Figure 1.1. Research Framework

\section{Literature Review and Research Hypotheses}

\subsection{Age}

Results from studies regarding age have been equivocal. Brockhaus, Cooper, Dunkelberg and Woo (1988) and Denison and Alexander (1982) have found evidence to suggest that older entrepreneurs are likely to survive or obtain higher income. Dunkelberg and Cooper (1982) have found that older entrepreneurs are less likely to experience growth. According to Bergmann and Sternberg (2007) and Fink (2015), level of entrepreneur's expertise and entrepreneurial propensity increases with the age. Therefore, they argue that older entrepreneurs are in a better position to predict the future and have control over it. Based on the above arguments, we posit the following hypotheses:

H1: Entrepreneur's age has a positive influence on entrepreneurial causation process.

\subsection{Education (formal and specialized)}

Numerous studies have been conducted in relation to the impact of education on entrepreneurial reward. According to Parker and van Praag (2006), the entrepreneurial function of "creative destruction" cannot be achieved if they face constraints such as human capital (education). Education can potentially be seen as a tool for supporting entrepreneurship (Tokila \& Tervo, 2010, p.690). The characteristics of entrepreneurial education programmes have been measured by three dimensions. In a study by Cruz, Escudero, Barahona, and Leitao (2009) entrepreneurial education has been characterized as: 'entrepreneurship education included courses in specialized educational centres and institutions and self-taught education in both further management education and entrepreneurship education. Specialized education includes education and training in business functions (marketing, finance, production, operations, etc.) and the core business' (p.202). While the third dimension of education is formal education. Cruz et al., (2009) have found that only entrepreneurship education has a direct and positive effect on satisfaction with innovation behaviour. Therefore, we propose the hypotheses:

H2a: Entrepreneur's special education will be positively related to entrepreneurial causation process.

H2b: Entrepreneur's education will be positively related to entrepreneurial causation process.

\subsection{Personality traits}

Personality theories have underscored the significance of personal predisposition for venture success (McClelland, 1965). Venture capitalists have reported that entrepreneurs' characteristics are extremely important to venture success (McMillan, Siegel \& SuhbaNarisimha (1985). Caprana and Cervone (2000) have defined personality traits as dispositions to exhibit a certain kind of response across various situations. Rauch and Frese (2000) have argued that personality traits 
are predictors of entrepreneurial behaviour. Also, Smith et al. (2001) have posited that contemporary leadership researchers have identified tenacity, passion, proactivity, goal-striving and self-confidence as characteristics of successful entrepreneurs. Ardichvili et al,. (2003) have found three personality traits that are related to successful opportunity recognition: optimism, self-efficacy, and creativity. In this study, proactivity, passion, and optimism have been considered as potential traits that can predict causation process.

Proactive personality is important in entrepreneurship study. Proactivity encapsulates the idea of individuals taking an active role in their environments by creating changes as opposed to simply reacting and accepting reluctantly without protest to the demands of their surroundings (Bateman \& Crant, 1993). Similarly, Rauch, Wiklund, Lumpkin, and Frese (2009) describe proactivity as an opportunity- seeking, forward-looking perspective characterized by the introduction of new services and products ahead of the competition and acting in anticipation of future demand. Crant (1996) has examined the relationship between the proactive personality scale and entrepreneurial intentions. Findings of the study have showed that a proactive personality is positively associated with entrepreneurial intentions. Also, Becherer and Maurer (1999) in their study find significant relationships between an entrepreneur's proactivity and the firm's competitive posture and growth in sales. An empirical study Kickul and Gundry (2002) find a significant relationship between proactive disposition of small business owners and the level of innovation in their implemented strategies. Proactive individuals anticipate and envision a future outcome, select, and modify situations in order to create that outcome. Proactive entrepreneurs within the building material industry in Nigeria have to consider causation process in determining opportunity. This is because there is a very high level of competition in building material industry in Nigeria. Entrepreneurs need to be proactive in their business to survive.

Passion is defined as a strong inclination toward an activity that people like, that they find important, and in which they invest time and energy (Vallerand et al., 2003). Two types of passion are proposed: obsessive and harmonious. "Obsessive passion" (OP) refers to a controlled internalisation of an activity in one's identity that creates an internal pressure to engage in the activity that the person likes. "Harmonious passion" (HP) refers to an autonomous internalisation that leads individuals to choose to engage in the activity that they like' (p.756). Alternately, passion is considered to be at the heart of the entrepreneur (Cardon, Zietsma, Saparito, Matherne, \& Davis, 2005). Passion can become the driving force for entrepreneurial action. Passion can fuel motivation, enhance mental activity, and provide meaning to everyday work (Brännback, Carsrud, Elfving \& Krueger, 2006). Passion is among micro level variables that may influence entrepreneurs' propensity to experience positive affect (Baron, 2008). Passion has been associated with the ability of entrepreneurs to raise funds from investors (Mitteness, Sudek, \& Cardon, 2012). According to numerous scholars, there is a need for a deeper understanding of passion construct Chen et al. (2009). Scholars in the field of leadership have argued that passion for work is a characteristic of successful business leaders (House \& Shamir, 1993). Passion is also argued to be relevant in an entrepreneurial setting because it drives entrepreneurs to face extreme uncertainty and resource shortages (Timmons, 2000). Entrepreneurs that are passionate about their business in the building material industry in Nigeria will survive the challenges and uncertainties.

Only a small portion of new businesses grow to become large enterprises in terms of revenues and employment (Cassar, 2006). Despite this reality, entrepreneurs that decide to forge ahead in the face of daunting obstacles suggest that they are high in dispositional optimism and deed (Hmieleski \& Baron, 2009). Researchers have documented the impact of different types of entrepreneurship on a nation's innovativeness and economic growth rate (Sternberg \& Wennekers, 2005). Scheier and Carver (1992) have defined optimism as the "tendency to believe that one will generally experience good vs bad outcomes in life" (p.203). Also, Fraser and Greene (2006, p. 169) stated that "optimistic beliefs may help individuals to overcome uncertainty and may, therefore, influence their entrepreneurial activity". Entrepreneurs are found to be more optimistic than employees, and the level of optimism and uncertainty diminishes with experience (Fraser \& Greene, 2006). Optimistic individuals are confident of achieving successful outcomes without being able to visualize the path that will get them there-simply believing that everything will work out favourably at the end (Scheier, Carver \& Bridges, 2001). In an empirical study Busenitz and Barney (1997) have demonstrated that entrepreneurs tend to overestimate the probability of being right and over generalize from a few characteristics or observations significantly more so than managers of large and established organisations. Alternatively, Hmieleski and Baron's (2009) study demonstrate a negative relationship between entrepreneurs' optimism and the performance (revenue and employment growth) of their new ventures. In general, studies of entrepreneurs' optimism have yielded mixed results. In a study by (Goodin et al., 2012) optimism has been significantly associated with enhanced condition pain modulation. In the building material industry optimism can have a significant relationship with causation process to explore opportunity. The fact that not all businesses grow to be successful enterprises, only optimistic entrepreneurs engage into a business venture. To survive in the building material industry entrepreneurs have to be Proactive, passionate, and optimistic. Based on the above arguments, we posit the following hypothesis: 


\section{H3: Entrepreneur's personality traits (proactivity, passion, and optimism) will be positively related to causation} process.

\subsection{Management skills}

The management and leadership schools have defined entrepreneurs as those who act and manage the business. The central focus of management school is that entrepreneurs are organisers of business venture; they are people who organise, own, manage and assume risks (Cunningham \& Lischeron, 1991). The school assumes that "entrepreneurs can be developed or trained in the technical functions of management. Moreover, entrepreneurs exhibit the following behaviours: production planning, people organising, capitalisation and budgeting" (Cunningham \& Lischeron, 1991.p.47). The Leadership school argues that entrepreneurs are leaders of people. They have the ability to adapt their style to the needs of people and the assumption is that "an entrepreneur cannot accomplish his/her goal alone, but depends on others. Entrepreneurs' behaviour and skills include motivating, directing and leading" (Cunningham \& Lischeron, 1991.p.47). These two schools of thoughts are combined into a single construct (management skills) which is also proposed to predict the choice of causation or effectuation.

According to Khan and Rocha (1982), owner/manager of a small business strengthens his/her managerial practice to avoid serious problems and eventual failure. They further state that managerial areas of accounting, cash flow management and marketing are interrelated, and the lack of knowledge in one of these areas may give rise to a problem in another area. One of the most frequently cited reason of reducing small business failure is increased management education (Sambasivan et al., 2009). In this research, we have combined two management skills and the dimensions of management skills are: social network and using other peoples' resources. Based on the above arguments we posit that:

H4: Entrepreneurs' management skills (social network and using other people's resources) will be positively related to entrepreneurial causation process.

\subsection{Causation}

The term causation is used by Sarasvathy (2001) to describe the traditional approach on entrepreneurship. In the causation model, individual entrepreneur decide on predetermined goal and select between means that predetermined goal (Sarasvathy, 2001). Entrepreneurship is viewed as "a linear process in which entrepreneur volition leads to gestational and planning activities" (Baker, Miner, \& Eesley, 2003, p.256). Causation involves "the process of discovery, evaluation and exploitation of opportunities" (Shane \& Venkataraman, 2000, p. 218). The central concept of causation are: opportunity identification and evaluation and deliberate exploitation of opportunities (Shane \& Venkataraman, 2000; Fisher, 2012). Entrepreneurs who engage in causation process embark on behaviours that include purposeful search and planning among other causal behaviours. Herron and Sapienza (1992) argue that purposeful search will be positively related to opportunity recognition. Ackelsberg and Arlow (1985) found that planning do pay off in terms of sales and profits. Based on the above arguments, we posit the following hypothesis:

H5. Entrepreneurial causation process will be positively related to entrepreneurial opportunity recognition process.

\section{Methodology}

The population of this study is made up of entrepreneurs who are retailers of building material from Nigeria. The sample firms were randomly selected from the list obtained from a Survey Report (MSMEs) In Nigeria (2010) published by National Bureau of Statistics and Small and Medium Enterprises Development Agency of Nigeria. Questionnaire was answered by owner managers within the building material trade. The questionnaire was built based on the constructs and items from previous studies. Questions for all dimensions were evaluated using a 7-point Likert scale. Data generated was analyzed using SmartPLS version 2.0. Normality was determined based on the skewness and kurtosis values (Hair et al., 2010; Hair et al., 2014). Values for skewness and kurtosis are given in Table 1.1 and many values are outside the acceptable thresholds of -3 and +3 . The choice for SmartPLS has been made based on the fact that the data for the present study is not normally distributed. Moreover, this framework has two constructs that are formative (Entrepreneur Education and Entrepreneur Special Education). According to Hair et al., (2010), these conditions make PLS- SEM suitable for analysing the relationship in the model. 
Table 1.1. Skewness and Kurtosis

\begin{tabular}{|c|c|c|c|c|c|c|c|}
\hline Items & $\mathrm{N}$ & Min & $\operatorname{Max}$ & Mean & Std. Dev & Skewness & Kurtosis \\
\hline PROAC & 360 & 1 & 7 & 5.76 & 1.214 & -1.542 & 3.572 \\
\hline PROAC & 360 & 2 & 7 & 5.78 & 1.135 & -.950 & .924 \\
\hline PROAC & 360 & 1 & 7 & 6.26 & 1.004 & -1.611 & 3.687 \\
\hline PROAC & 360 & 1 & 7 & 6.17 & .950 & -1.534 & 4.253 \\
\hline PROAC & 360 & 1 & 7 & 6.00 & 1.103 & -1.144 & 1.469 \\
\hline PROAC & 360 & 1 & 7 & 5.86 & 1.034 & -1.006 & 2.179 \\
\hline PASS & 360 & 1 & 7 & 5.31 & 1.280 & -.819 & .791 \\
\hline PASS & 360 & 1 & 7 & 5.62 & 1.236 & -1.075 & 1.719 \\
\hline PASS & 360 & 1 & 7 & 5.24 & 1.141 & -.286 & -.012 \\
\hline PASS & 360 & 1 & 7 & 5.53 & 1.192 & -1.086 & 1.896 \\
\hline OPTM & 360 & 1 & 7 & 5.88 & 1.169 & -1.202 & 2.084 \\
\hline OPTM & 360 & 1 & 7 & 5.36 & 1.239 & -.510 & .091 \\
\hline OPTM & 360 & 2 & 7 & 5.77 & 1.224 & -.826 & .117 \\
\hline OPTM & 360 & 1 & 7 & 5.87 & 1.321 & -1.375 & 2.082 \\
\hline OPTM & 360 & 1 & 7 & 6.23 & 1.037 & -1.816 & 4.504 \\
\hline OPTM & 360 & 1 & 7 & 5.73 & 1.083 & -.997 & 1.680 \\
\hline MAGTSNetwork & 360 & 1 & 7 & 5.29 & 1.521 & -.693 & -.212 \\
\hline MAGTSNetworl & 360 & 1 & 7 & 5.28 & 1.546 & -.840 & .099 \\
\hline MAGTSNetwork & 360 & 1 & 7 & 5.37 & 1.564 & -.809 & -.128 \\
\hline MAGTSNetwork & 360 & 1 & 7 & 5.04 & 1.589 & -.625 & -.409 \\
\hline MAGT Other Peoples' & 360 & 1 & 7 & 5.97 & 1.265 & -1.478 & 2.172 \\
\hline MAGTOther Peoples' & 360 & 1 & 7 & 5.86 & 1.175 & -1.390 & 2.641 \\
\hline MAGT Other Peoples' & 360 & 1 & 7 & 5.77 & 1.182 & -1.080 & 1.253 \\
\hline MAGT Other peoples' & 360 & 1 & 7 & 5.69 & 1.441 & -1.348 & 1.636 \\
\hline CAUS & 360 & 1 & 7 & 5.94 & .954 & -1.049 & 2.911 \\
\hline CAUS & 360 & 2 & 7 & 5.98 & .922 & -.649 & .566 \\
\hline CAUS & 360 & 1 & 7 & 6.32 & .920 & -1.619 & 4.768 \\
\hline CAUS & 360 & 1 & 7 & 6.22 & .879 & -1.527 & 5.455 \\
\hline CAUS & 360 & 1 & 7 & 6.10 & 1.012 & -1.250 & 2.459 \\
\hline CAUS & 360 & 1 & 7 & 5.98 & .938 & -1.015 & 2.949 \\
\hline CAUS & 360 & 1 & 7 & 5.85 & 1.062 & -.928 & 1.350 \\
\hline EFFEXP & 360 & 2 & 7 & 3.98 & .864 & .319 & 1.351 \\
\hline EFFEXP & 360 & 1 & 7 & 3.89 & 1.074 & 540 & 1.423 \\
\hline EFFEXP & 360 & 1 & 7 & 3.84 & 1.025 & .050 & .532 \\
\hline EFFEXP & 360 & 2 & 7 & 4.01 & .923 & .619 & 1.787 \\
\hline EFFAL & 360 & 1 & 7 & 6.28 & .853 & -1.771 & 6.904 \\
\hline EFFAL & 360 & 1 & 7 & 6.11 & 1.043 & -1.343 & 2.433 \\
\hline EFFAL & 360 & 1 & 7 & 5.98 & 1.011 & -1.170 & 2.897 \\
\hline EFFLEX & 360 & 1 & 7 & 6.17 & 1.082 & -1.651 & 3.441 \\
\hline EFFLEX & 360 & 1 & 7 & 5.92 & 1.305 & -1.168 & 1.008 \\
\hline EFFLEX & 360 & 1 & 7 & 5.74 & 1.385 & -1.185 & .901 \\
\hline EFFLEX & 360 & 1 & 7 & 5.26 & 1.216 & -.715 & .505 \\
\hline \multicolumn{8}{|c|}{ te: EFFEXP: Effectual Experimentat } \\
\hline ffectual Af & & & & & & & \\
\hline
\end{tabular}

\section{Measures}

Measure for education is from Cruz et al (2009). The number of items under this construct is 8. Some are: (1) Management education courses in educational centres and institutions; (2) entrepreneurial education courses in education centres and institutions; (3) self-taught further management education.

The construct entrepreneur proactivity has 6 items from Bateman and Crant (1993). The followings are some of the items: (1) I am constantly on the lookout for new ways to improve my life; (2) I feel driven to make a difference in my community, and maybe the world. 
Measures for Entrepreneurs' Optimism have been adopted from Scheier, Carver, and Bridges, (1994). The following are some of the items linked to optimism: (1) In uncertain times, I usually expect the best; (2) Overall, I expect more good things to happen to me than bad.

Measures for passion are from Cardon, Gregoire, Stevens, and Patel (2012). The followings are some of the items that measured entrepreneurs' passion: (1) I like finding the right people to market my product; (2) Assembling the right people to work for my business is exciting.

Measure for management skills (social network) are from Forret and Dougherty (2001). Some of the items are: (1) Give business contacts and phone to keep in touch; (2) Sent thank you notes and gifts to others who have helped you in your work.

The items for using other peoples' resources are from Winborg and Landström (2001) and some of the items are: (1) Delay payments to suppliers; (2) Delay payments for value-added tax.

The items for causation are from Chandler et al., (2011). Causation has 7 items. Some of the items are: (1) I analysed long run opportunities and selected what I thought would provide the best returns; (2) I developed a strategy to take the best advantage of resources and capabilities.

\section{Sample}

Companies listed in the 2010 survey by Small and Medium Enterprise Development Agency of Nigeria and National Bureau of Statistics forms the population frame for this research. The list provides 22, 918 registered SMEs in all 36 states and Federal Capital Territory. For the purpose of this study, 21 states from Nigerian four Geo -political zones were selected: North - West, North - East, South -West and South - East, for the purpose of administration of the questionnaire. All states in the North West (Kaduna, Kano, Kebbi, Sokoto, Jigawa, Katsina and Zamfara) and three out of six states in the North - East (Gombe, Bauchi, Taraba) were selected. For security reasons Borno, Yobe, and Adamawa were not considered. From the South - West three states (Oyo, Osun and Lagos) were selected. Lastly, three states were selected from South-East: Abia, Anambra and Ebonyi. Over 21 percent (4900) of the total registered SMEs were found in these states and were retailers of building materials. These different geopolitical zones were chosen to have a fair representation of religious, cultural, ethnic and social diversity that are found in Nigeria. A total of 1,950 questionnaires were sent. 230 responses were received during the first wave. After follow up, 130 additional responses were collected. An independent t-test was performed on all constructs in the model, and analysis of the results did not indicate major differences between the early and late responders. These results collectively suggest that non-response bias did not influence the survey data. The results of the test are given in Table 1.2. Since each questionnaire was filled by a single respondent, we tested for the existence of common variance bias using Harman one-factor test. Based on the results of the test, it was found that the co-variance explained by a single factor was $27.30 \%$, implying that common variance bias was not a threat in this research.

Table 1.2. t-test for non response bias

\begin{tabular}{llcccc}
\hline & & \multicolumn{3}{c}{ t-test for Equality of Means } \\
& & Equal variances assumed & .266 & 358 & .791 \\
PROAC1 & Equal variances not assumed & .272 & 286.575 & .786 \\
& Equal variances assumed & .265 & 358 & .791 \\
PROAC2 & Equal variances not assumed & .271 & 285.937 & .786 \\
PROAC3 & Equal variances assumed & .252 & 358 & .801 \\
& Equal variances not assumed & .258 & 287.802 & .797 \\
PROAC4 & Equal variances assumed & 1.233 & 358 & .218 \\
& Equal variances not assumed & 1.243 & 274.224 & .215 \\
PROAC5 & Equal variances assumed & .036 & 358 & .971 \\
& Equal variances not assumed & .037 & 283.304 & .971 \\
PROAC6 & Equal variances assumed & -.680 & 358 & .497 \\
& Equal variances not assumed & -.712 & 304.696 & .477 \\
PASS7 & Equal variances assumed & -.623 & 358 & .534 \\
& Equal variances not assumed & -.630 & 276.063 & .529 \\
PASS8 & Equal variances assumed & -.719 & 358 & .472 \\
& Equal variances not assumed & -.751 & 303.148 & .453 \\
\hline
\end{tabular}




\begin{tabular}{|c|c|c|c|c|}
\hline \multirow{2}{*}{ PASS9 } & Equal variances assumed & .005 & 358 & .996 \\
\hline & Equal variances not assumed & .005 & 277.202 & .996 \\
\hline \multirow{2}{*}{ PASS10 } & Equal variances assumed & -.095 & 358 & .925 \\
\hline & Equal variances not assumed & -.096 & 280.910 & .924 \\
\hline \multirow{2}{*}{ OPTM11 } & Equal variances assumed & .010 & 358 & .992 \\
\hline & Equal variances not assumed & .011 & 293.641 & .991 \\
\hline \multirow{2}{*}{ OPTM12 } & Equal variances assumed & -.005 & 358 & .996 \\
\hline & Equal variances not assumed & -.005 & 284.791 & .996 \\
\hline \multirow{2}{*}{ OPTM13 } & Equal variances assumed & -.445 & 358 & .656 \\
\hline & Equal variances not assumed & -.454 & 284.219 & .650 \\
\hline \multirow{2}{*}{ OPTM14 } & Equal variances assumed & -.828 & 358 & .408 \\
\hline & Equal variances not assumed & -.850 & 289.615 & .396 \\
\hline \multirow{2}{*}{ OPTM15 } & Equal variances assumed & -.214 & 358 & .830 \\
\hline & Equal variances not assumed & -.223 & 301.197 & .824 \\
\hline \multirow{2}{*}{ OPTM16 } & Equal variances assumed & -.610 & 358 & .542 \\
\hline & Equal variances not assumed & -.632 & 295.863 & .528 \\
\hline \multirow{2}{*}{ MAGTSNetwork17 } & Equal variances assumed & -.727 & 358 & .468 \\
\hline & Equal variances not assumed & -.735 & 276.488 & .463 \\
\hline \multirow{2}{*}{ MAGTSNetworl18 } & Equal variances assumed & -.656 & 358 & .512 \\
\hline & Equal variances not assumed & -.656 & 267.437 & .513 \\
\hline \multirow{2}{*}{ MAGTSNetwork19 } & Equal variances assumed & .212 & 358 & .832 \\
\hline & Equal variances not assumed & .214 & 276.210 & .830 \\
\hline \multirow{2}{*}{ MAGTSNetwork20 } & Equal variances assumed & -.159 & 358 & .874 \\
\hline & Equal variances not assumed & -.160 & 275.467 & .873 \\
\hline \multirow{2}{*}{ MAGT Other Peoples' 21} & Equal variances assumed & -1.125 & 358 & .261 \\
\hline & Equal variances not assumed & -1.187 & 311.596 & .236 \\
\hline \multirow{2}{*}{ MAGTOther Peoples' 22} & Equal variances assumed & -1.442 & 358 & .150 \\
\hline & Equal variances not assumed & -1.524 & 313.126 & .129 \\
\hline \multirow{2}{*}{ MAGT Other Peoples' 23} & Equal variances assumed & -.554 & 358 & .580 \\
\hline & Equal variances not assumed & -.573 & 295.571 & .567 \\
\hline \multirow{2}{*}{ MAGT Other peoples'24 } & Equal variances assumed & -.442 & 358 & .659 \\
\hline & Equal variances not assumed & -.452 & 286.068 & .652 \\
\hline \multirow{2}{*}{ CAUS25 } & Equal variances assumed & .204 & 358 & .838 \\
\hline & Equal variances not assumed & .209 & 285.416 & .835 \\
\hline & Equal variances assumed & -.063 & 358 & .950 \\
\hline CAUSZO & Equal variances not assumed & -.065 & 294.514 & .948 \\
\hline & Equal variances assumed & -.337 & 358 & .736 \\
\hline CAUSZI & Equal variances not assumed & -.352 & 302.543 & .725 \\
\hline & Equal variances assumed & -.104 & 358 & .917 \\
\hline CAUS28 & Equal variances not assumed & -.110 & 311.802 & .913 \\
\hline CAUS29 & Equal variances assumed & -.472 & 358 & .637 \\
\hline LAUSZY & Equal variances not assumed & -.490 & 298.103 & .624 \\
\hline & Equal variances assumed & -.454 & 358 & .650 \\
\hline CAUS3O & Equal variances not assumed & -.466 & 288.297 & .642 \\
\hline & Equal variances assumed & -.089 & 358 & .929 \\
\hline CAUS31 & Equal variances not assumed & -.091 & 287.296 & .928 \\
\hline OPRFC43 & Equal variances assumed & -1.604 & 358 & .110 \\
\hline UPREL 43 & Equal variances not assumed & -1.706 & 318.218 & .089 \\
\hline & Equal variances assumed & .097 & 358 & .923 \\
\hline UPREC44 & Equal variances not assumed & .097 & 272.478 & .923 \\
\hline & Equal variances assumed & 1.404 & 358 & .161 \\
\hline UPREC45 & Equal variances not assumed & 1.411 & 272.141 & .159 \\
\hline & Equal variances assumed & -.403 & 358 & .687 \\
\hline Entr. Educ.bs & Equal variances not assumed & -.405 & 270.984 & .686 \\
\hline & Equal variances assumed & 1.432 & 358 & .153 \\
\hline Entr. Edu.b6 & Equal variances not assumed & 1.441 & 273.053 & .151 \\
\hline & Equal variances assumed & 1.345 & 358 & .180 \\
\hline Entr.Edu.6r & Equal variances not assumed & 1.313 & 248.960 & .191 \\
\hline & Equal variances assumed & -1.648 & 358 & .100 \\
\hline Entr. Educ.b8 & Equal variances not assumed & -1.605 & 247.182 & .110 \\
\hline
\end{tabular}




\begin{tabular}{llccc}
\hline Entr. Spec.Educ 69 & Equal variances assumed & -1.312 & 358 & .190 \\
& Equal variances not assumed & -1.272 & 244.176 & .205 \\
Entr. Spec.Educ 70 & Equal variances assumed & -1.711 & 358 & .088 \\
& Equal variances not assumed & -1.668 & 247.994 & .097 \\
Entr. Spec.Educ 71 & Equal variances assumed & -.591 & 358 & .555 \\
& Equal variances not assumed & -.596 & 274.712 & .552 \\
\hline
\end{tabular}

Also variance inflation factor (VIF) was used to assess the problem of multicollinearity. The multicollinearity diagnostic indicated that VIF's of the five independent variables, antecedents of entrepreneurial causation process, fell in the range between 1.191 to 2.099 which is less than the threshold value of five (Hair et al., 2010). Therefore, we conclude that multi-collinearity is not a serious issue in this research.

\section{Reliability and Validity}

The survey items used to measure formative constructs are not expected to be highly correlated. Thus, conventional tests of reliability and validity are not applicable to assessment of formative measures. Instead, formative measures were evaluated for multicollinearity and the item weights of the indicators were assessed. As such, the item weights and significance of the formative survey items in the model were calculated and are presented in Table 1.3. A review of these results reveals that several of the formative constructs do not have items with nonsignificant weights. The results, suggest that multicollinearity is not a concern as all VIF values in the model are not more than the acceptable threshold of 3.3 as recommended by Diamantopoulos and Siguaw (2006). Hence, the results of this analysis indicate that all formative constructs in the model demonstrate sufficient validity.

Table 1.3. Items weights, significance and VIF

\begin{tabular}{lcccc}
\hline Constructs/items & Outer weights & t-statistics & & Collinearity Statistics \\
\hline & & & Tolerance & Variance Inflation Factors (VIF) \\
Entrepreneur Special Education & & & & \\
Entr. Spe Edu. & 0.6184 & 1.2914 & 0.872 & 1.147 \\
Entr. Spe. Edu. & -0.7576 & 1.316 & 0.791 & 1.263 \\
Entre Spe. Edu & 0.274 & 0.6277 & 0.914 & 1.094 \\
Entr. Spe. Edu. & 0.6729 & 1.3329 & 0.941 & 1.063 \\
Entrepreneur Education & & & & \\
Entr. Edu. & 0.6032 & 2.2195 & 0.949 & 1.054 \\
Entr. Edu & 0.5256 & 1.8562 & 0.936 & 1.068 \\
Entr. Edu & 0.7154 & 2.9698 & 0.944 & 1.059 \\
Entr. Edu & 0.5332 & 0.9749 & 0.877 & 1.14 \\
\hline
\end{tabular}

Validity and reliability for reflective constructs were based on these indicators: internal consistency, reliability, convergent validity and discriminant validity. Measurement models are deemed to have adequate consistency reliability if the composite reliability (CR) of the constructs within the model exceeds the threshold value of 0.7.Table 1.4 below exhibits $\mathrm{CR}$ and average variance extracted (AVE). The average variance extracted is above the 0.5 which is sufficient for convergent validity (Fornell \& Larcker, 1981).

Table 1.4. Composite reliability and average variance extracted

\begin{tabular}{lcccccc}
\hline Construct & Item & AVE & Mean & Std Dev. & Loadings & T-Statistics \\
Proactivity & PROAC002 & 0.6123 & 0.1816 & 0.0168 & 0.6574 & 10.7427 \\
CR $=0.8869$ & PROAC003 & 0.2307 & 0.0164 & 0.7822 & 14.1742 \\
& PROAC004 & 0.2606 & 0.0139 & 0.8313 & 18.7963 \\
& PROAC005 & 0.2766 & 0.0183 & 0.7891 & 14.9959 \\
& PROAC006 & 0.3184 & 0.0228 & 0.839 & 13.8547 \\
Passion & PASS007 & 0.5486 & 0.232 & 0.0369 & 0.658 & 6.4233 \\
CR $=0.8282$ & PASS008 & 0.4056 & 0.03 & 0.8358 & 13.4087 \\
& PASS009 & 0.3878 & 0.0373 & 0.7607 & 10.3328 \\
& PASS010 & 0.3052 & 0.0281 & 0.6959 & 10.9727 \\
\hline
\end{tabular}




\begin{tabular}{|c|c|c|c|c|c|c|}
\hline Optimism & OPTM011 & 0.5249 & 0.2802 & 0.0229 & 0.7514 & 12.1011 \\
\hline \multirow[t]{5}{*}{$\mathrm{CR}=0.8687$} & OPTM012 & & 0.2217 & 0.018 & 0.6938 & 12.2494 \\
\hline & ОРТМ013 & & 0.199 & 0.0172 & 0.6954 & 11.5278 \\
\hline & OPTM014 & & 0.1917 & 0.0162 & 0.6973 & 11.8578 \\
\hline & ОРТМ015 & & 0.2456 & 0.0144 & 0.756 & 17.1449 \\
\hline & OPTM016 & & 0.2407 & 0.014 & 0.7498 & 17.1614 \\
\hline Social Network & SNFS017 & 0.7438 & 0.2691 & 0.0179 & 0.8864 & 15.0227 \\
\hline \multirow[t]{3}{*}{$C R=0.9206$} & SNF018 & & 0.3139 & 0.0161 & 0.8749 & 19.4584 \\
\hline & SNF019 & & 0.3121 & 0.0174 & 0.8835 & 17.9948 \\
\hline & SNF020 & & 0.2635 & 0.0229 & 0.8022 & 11.4769 \\
\hline Using other peoples resources & OPR021 & 0.7885 & 0.39 & 0.0126 & 0.8872 & 30.7904 \\
\hline \multirow[t]{3}{*}{$C R=0.9179$} & OPR022 & & 0.3952 & 0.0131 & 0.8911 & 30.183 \\
\hline & OPR023 & & 0.3424 & 0.011 & 0.8856 & 31.0937 \\
\hline & OPR024 & & 0.2877 & 0.0621 & 0.8209 & 4.7619 \\
\hline Causation & CAUS025 & 0.6064 & 0.2051 & 0.0336 & 0.7984 & 5.9796 \\
\hline \multirow[t]{6}{*}{$C R=0.9149$} & CAUS026 & & 0.1524 & 0.0317 & 0.6807 & 4.8613 \\
\hline & CAUS027 & & 0.2151 & 0.0281 & 0.7898 & 7.5508 \\
\hline & CAUS028 & & 0.1386 & 0.0374 & 0.7924 & 3.9786 \\
\hline & CAUS029 & & 0.1896 & 0.0303 & 0.7583 & 6.1522 \\
\hline & CAUS030 & & 0.1741 & 0.027 & 0.826 & 6.5552 \\
\hline & CAUS031 & & 0.2093 & 0.0318 & 0.7969 & 6.3801 \\
\hline Opportunity Recognition & OPREC043 & 0.6604 & 0.4016 & 0.0233 & 0.8259 & 17.2954 \\
\hline \multirow[t]{2}{*}{$C R=0.8536$} & OPREC044 & & 0.4176 & 0.0292 & 0.8087 & 14.2471 \\
\hline & OPREC045 & & 0.4131 & 0.0267 & 0.8031 & 15.4081 \\
\hline
\end{tabular}

\section{Data Analysis and Results}

Over $98 \%$ of the respondents are male this is not surprising considering the nature of building materials. Respondents are from different ethnicity majority from Ibo race with $43.1 \%$, followed by Yoruba with $23.9 \%$, Hausa/Fulani $20.6 \%$, and $12.5 \%$ from other ethnic races. $28.9 \%$ are age between $46 y e a r s$ and above, and $25.8 \%$ of the respondents are age between $44-49$ years. Over 19\% are having National Diploma and 10.8\% have Doctor Degree.

Structural equation modelling (PLS-SEM) is an exploratory analysis technique. It is the objective of this study to investigate factors that influence causation and the influence of causation process on opportunity recognition process. The study's hypotheses have been tested using PLS-SEM to test the strength of relationship. We have run PLS-SEM models using SmartPLS 2.0. The SmartPLS bootstrapping function was used to generate the t-statistics values, and Microsoft excel was used to calculate exact $p$. value and SmartPLS algorithm function was used to obtain the $\mathrm{R}^{2}$ values. In this study, the bootstrapping generated 5000 samples from 360 cases. In the second model we have entrepreneur age, entrepreneur education, entrepreneur special education, personality traits, and management skills as the exogenous variables. The PLS-Variance output for the model is given in Table 1.5 and Figure 1.2 respectively. In first model the exogenous variable is causation and opportunity recognition is endogenous.

The five antecedents of entrepreneurial causation process produced $75.2 \%$ increment in total variance explain when all the five factors were added. Among these factors only entrepreneurial age was not significant see Table 1.5. Therefore, $\mathrm{H} 2 \mathrm{~A}, \mathrm{H} 2 \mathrm{~B}, \mathrm{H} 3$, and $\mathrm{H} 4$ were all supported except $\mathrm{H} 1$ which is not supported. Additional relationship was tested results of the test revealed that entrepreneurial causation process significantly influence opportunity recognition process, therefore $\mathrm{H} 5$ was supported.

The results reveal that entrepreneurial management skill had the highest coefficient $(\beta-0.501)$ and was found to be the most important variable for predicting entrepreneurial causation process. Entrepreneurial personality traits variable $(\beta-0.316)$ is the second most important of the antecedents of entrepreneurial causation process. Entrepreneurial special education and entrepreneurial education are the next important variables $(\beta-0.138, \beta 0-134)$ among the antecedents of entrepreneurial causation process. In sum, these four factors plays critical role in predicting entrepreneurial causation process.

The one antecedent of opportunity recognition, entrepreneurial causation produced $51.7 \%$ increment in total variance explains when entrepreneurial causation process was regressed on opportunity recognition process. Therefore, H5 was supported. 
Table 1.5. Path Coefficient, $t-S t a t i s t i c s$ and significant level for main relationship

\begin{tabular}{|c|l|c|c|c|}
\hline & Relationship & Path Coefficient $\beta$ & t- Statistics & p. value $0.05 \%$ \\
\hline H1 & Entrepreneur Age $\rightarrow$ Causation & 0.010 & 0.2977 & 0.7662 \\
\hline H2A & Entrepreneur Special Education $\rightarrow$ Causation & 0.138 & 4.6154 & $0.000^{*}$ \\
\hline H2B & Entrepreneur Education $\rightarrow$ Causation & 0.134 & 3.9025 & $0.0001^{*}$ \\
\hline H3 & Personality Traits $\rightarrow$ Causation & 0.316 & 4.8137 & $0.0000^{*}$ \\
\hline H4 & Management Skills $\rightarrow$ Causation & 0.501 & 8.6842 & $0.0000^{*}$ \\
\hline H5 & Causation $\rightarrow$ Opportunity Recognition & 0.720 & 4.4254 & $0.0000^{*}$ \\
\hline
\end{tabular}

* Significant at $0.05 \%$ significance level

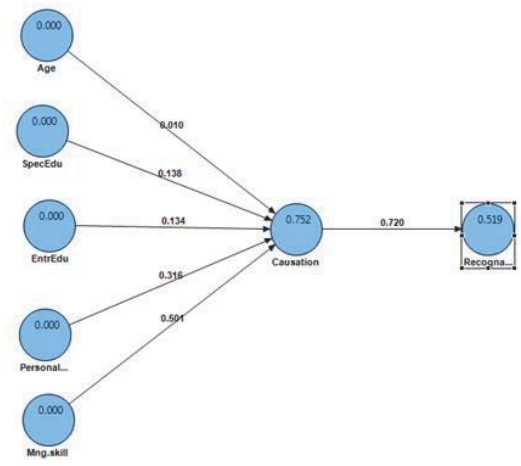

Figure 1.2. Research framework with main relationship

\section{Discussion}

Antecedents of entrepreneurial causation process: This study developed a model by exploring 'great person' and psychological theories into a single construct entrepreneurial personality traits. Also, combined management and leadership theories into a single construct entrepreneurial management skill as antecedents of entrepreneurial causation process. Most entrepreneurial opportunity studies have been limited to antecedents of opportunity recognition. This study extends the existing literature by exploring antecedents of entrepreneurial causation processes. The findings of this study confirmed that entrepreneur's characteristics in the form of entrepreneur special education, entrepreneur education, personality traits and management skill are significant to entrepreneurial causation process. Again, the study further examined the relationship between entrepreneurial causation process and opportunity recognition. The findings suggest that entrepreneurial causation process is significant predictor of opportunity recognition. Harms and Schiele (2012) is the only study that considered antecedents of causation and effectuation in International New Venture Creation process. The present study departed from Harms and Schiele's study by identifying antecedents of Causation in small business enterprises (Retail business). Why are the antecedences of Causation Important? Predominant approach to exploitation of entrepreneurial opportunity is the neoclassical theory (Fisher, 2012; Chandler et al., 2011), this approach is consistent with causation process (Sarasvathy, 2001). Lately, the validity of this approach has been questioned by numerous scholars (Read, Dew, Sarasvathy, Song, \& Wiltbank, 2009). The argument as observed by (Sarasvathy, 2001) is that causation approach "is useful in static, linear, and independent environment" (p.251). Causation approach might not be useful "in a dynamic, nonlinear and ecological environment" (p.251). Considering the existence of static environments within the business realm exploring factors that will predict the process is a welcome academic exercise. Identifying factors that will influence causation process can impact on training of entrepreneurs, through appropriate training entrepreneurs can be trained to recognise opportunity (Baron, 2007).

The findings of this study have relevance to government, educators and human resource professional. Entrepreneurial age was not found to influence the entrepreneurial causation process. Entrepreneurial causation process is the predominant decision model in business schools. Those entrepreneurs with knowledge of business models are susceptible to engage in causal process, so age is irrelevant. 
In this study results have shown that entrepreneur special education has positive relationship with causation process. Both entrepreneur education and entrepreneurial special education has positive relationship with causation process. On the bases this study we suggest that government and nongovernmental organisations who spend large amount of money for training, should train prospective entrepreneurs in both types of education, in order to identify and exploit opportunity in static business environment.

Personality traits have positive relationship with causation; therefore, recognising the importance entrepreneurs' personality traits in form of proactivity becomes a critical endeavour. Training aimed at rekindling proactive behaviour can help individual entrepreneurs to engage in causation process as well as recognising entrepreneurial opportunity.

Management skill has positive relationship with causation. It is also worthy to note that entrepreneurial management skill in form of using other people's resources is having a significant effect on entrepreneurial causation process. Thus, training entrepreneurs to engage in using other people's resources will be an important task for schools, nongovernmental organisations and professionals offering entrepreneurial training.

Therefore training programmes designed to train entrepreneurs on 'entrepreneurial process of causation' must acknowledge entrepreneur special education, entrepreneur education, personality traits, and management skills. These factors enhance and heightened the ability of entrepreneurs to engage on causation process more than other factors.

\section{Conclusion Recommendation and Direction for Further Study}

The first contribution of this study was exploring factors that influence causation process of opportunity exploitation. We theoretically and empirically explore the influences of Entrepreneur's Age, Entrepreneur special education; entrepreneur education; personality traits; and management skills on causation process. Secondly, we extended Sarasvathy's (2001) causation into the field of retail trade. Third, we developed a theoretical framework that combine various theories of entrepreneurship and validated them through conducting a quantitative study. The results show that: entrepreneurial process of causation is positively affected by entrepreneur special education; entrepreneur education; personality traits and management skills

One of the limitations of this study is that findings are limited to Nigeria. Two, sample covers only retail business in building material industry. Three, the causal effect of this study cannot be empirically validates because the study is cross-sectional in nature.

Future studies can be in other types of industry, and a longitudinal study can be considered with an in depth interview. Future study can explore other variables other than those considered in the present study.

\section{References}

Ackelsberg, R., \& Arlow, P. (1985). Small Businesses Pays Off * Do Plan and It. Long Range Planning, 18(5), 61-67.

Alvarez, S. A., \& Barney, J. B. (2010). Entrepreneurship and Epistemology: The Philosophical Underpinnings of the Study of Entrepreneurial Opportunities. The Academy of Management Annals, 4(1), 557-583.

Alvarez, S., \& Barney, J. (2007). Discovery and creation: Alternative theories of entrepreneurial action. Strategic Entrepreneurship Journal, 26(November), 11-26.

Ardichvili, A., Cardozo, R., \& Ray, S. (2003). A theory of entrepreneurial opportunity identification and development. Journal of Business Venturing, 18(1), 105-123.

Baker, T., Miner, A. S., \& Eesley, D. T. (2003). Improvising firms: Bricolage, account giving and improvisational competencies in the founding process. Research Policy, 32(2 SPEC.), 255-276.

Baron, R. A. (2007). Opportunity Recognition as Pattern Recognition : How Entrepreneurs "connect the Dots " to identify new Business Opportunities. Academy of Management Perspectives, 21(1), 104-120.

Baron, R. a. (2008). The Role of Affect in the Entrepreneurial Process. Academy of Management Review, 33(2), 328-340.

Bateman, T., \& Crant, J. (1993). The proactive component of organizational behavior: A measure and correlates. Journal of Organizational Behavior, 14(August 1992), 103-118.

Baum, J. R., Locke, E. A., \& Smith, K. G. (2001). a Multidimensional Model of Venture Growth. Academy of Management Journal, 44(2), 292-303.

Becherer, R., \& Maurer, J. (1999). The proactive personality disposition and entrepreneurial behavior among small company presidents. ... Business ..., 37(1), 28-37.

Bird, B. J. (1989). Entrepreneurial behavior. Reading, MA: Addison-Wesley.

Brännback, M., Carsrud, A., Elfving, J., Krueger, N. K. (2006). Sex, [drugs], and entrepreneurial passion? An exploratory study. Paper Presented at the Babson College Entrepreneurship Research Conference. Bloomington, IN.

Busenitz, L. W., \& Barney, J. B. (1997). Differences between entrepreneurs and managers in large organizations: Biases and heuristics in strategic decision-making. Journal of Business Venturing, 12(1), 9-30. 
Caprana, G. V., \& Cervone, C. (2000). Personality: Determinants, dynamics, and potentials. New York: Cambridge University Press.

Cardon, M. S., Gregoire, D. a., Stevens, C. E., \& Patel, P. C. (2012). Measuring entrepreneurial passion: Conceptual foundations and scale validation. Journal of Business Venturing, 28(3), 373-396.

Cardon, M. S., Zietsma, C., Saparito, P., Matherne, B. P., \& Davis, C. (2005). A tale of passion: New insights into entrepreneurship from a parenthood metaphor. Journal of Business Venturing, 20(1), 23-45.

Cassar, G. (2006). Entrepreneur opportunity costs and intended venture growth. Journal of Business Venturing, 21(5), 610-632.

Chandler, G. N., DeTienne, D. R., McKelvie, A., \& Mumford, T. V. (2011). Causation and effectuation processes: A validation study. Journal of Business Venturing, 26(3), 375-390.

Chen, X.-P., Yao, X., \& Kotha, S. (2009). Entrepreneur Passion And Preparedness In Business Plan Presentations: A Persuasion Analysis Of Venture Capitalists' Funding Decisions. Academy of Management Journal, 52(1), 199-214.

Crant, J. (1996). The proactive personality scale as a predictor of entrepreneurial intentions. Management, 34(3), 42-50.

Cruz, N. M., Escudero, A. I. R., Barahona, J. H., \& Leitao, F. S. (2009). The effect of entrepreneurship education programmes on satisfaction with innovation behaviour and performance. Journal of European Industrial Training, 33(3), 198-214.

Cunningham, J., \& Lischeron, J. (1991). Defining entrepreneurship. Journal of Small Business Management, 29(1), 45-62.

Diamantopoulos, A., \& Siguaw, J. a. (2006). Formative Versus Reflective Indicators in Organizational Measure Development: A Comparison and Empirical Illustration. British Journal of Management, 17(4), 263-282.

Eisenhardt, K., Kotha, S., Meyer, A., \& Rajagopalan, N. (2010). Technology entrepreneurship: Call for papers for a special issue. Strategic Entrepreneurship Journal.

Fiet, J. O. (2002). The Systematic Search for Entrepreneurial Discoveries. Quorum Books, Westport, CT.

Fisher, G. (2012). Effectuation, Causation, and Bricolage: A Behavioral Comparison of Emerging Theories in Entrepreneurship Research. Entrepreneurship Theory and Practice, 36(5), 1019-1051.

Fornell, C., \& Larcker, D. F. (1981). Evaluating Structural Equation Models with Unobservable Variables and Measurement Error. Journal of Marketing Research (JMR). Feb1981, 18(1), 39-50. 12p. 1 Diagram.

Forret, M. L., \& Dougherty, T. W. (2001). Correlates of Networking Behavior for Managerial and Professional Employees. Group \& Organization Management, 26(3), 283-311.

Fraser, S., \& Greene, F. J. (2006). The Effects of Experience on Entrepreneurial Optimism and Uncertainty. Economica, 73(290), 169192.

Goodin, B. R., Kronfli, T., King, C. D., Glover, T. L., Sibille, K., \& Fillingim, R. B. (2012). Testing the relation between dispositional optimism and conditioned pain modulation: does ethnicity matter? Journal of Behavioral Medicine, 36(2), 165-74.

Hair, J. F., Black, W. C., Babin, B. J., \& Anderson, R. E. (2010). Multivariate data analysis. New Jersey: Prentice Hall.

Harms, R., \& Schiele, H. (2012). Antecedents and consequences of effectuation and causation in the international new venture creation process. Journal of International Entrepreneurship, 10(2), 95-116.

Herron, L., \& Sapienza, H. (1992). The entrepreneur and the initiation of new venture launch activities. Entrepreneurship : Theory and Practice, 17(1), 49-56.

Hmieleski, K. M., \& Baron, R. a. (2009). Entrepreneurs' Optimism And New Venture Performance: A Social Cognitive Perspective. Academy of Management Journal, 52(3), 473-488.

House, R. J., \& Shamir, B. (1993). Toward the integration of transformational, charismatic and visionary theories of leadership. In M. Chemers \& R. Ayman (Eds.),Leadership theory and research: Perspectives and directions(pp. 81-107). San Diego, CA: Academic Press.

Josep F. Hair, J., Hult, G. T. M., Ringle, C. M., \& Sarstedt, M. (2014). A Primer on Partial Least Squares Structral Equation Modeling (PLS-SEEM).

Khan, M., \& Rocha, J. (1982). Recurring managerial problems in small business. ... Journal of Small Business, 7(1), 50-59.

Kickul, J., \& Gundry, L. (2002). Prospecting for strategic advantage: the proactive entrepreneurial personality and small firm innovation. Journal of Small Business Management, 40(2), 85-97.

Lau, T., Chan, K. F., \& Ho, R. (2004). Cross-Border Entrepreneurs - A Study of the changing Strategies and Competencies of Hong Kong Entrepreneurs Upon Exposure to the Emerging Market of China. Journal of Enterprising Culture.

Lin, C. Y.-Y. (1998). Success Factors of Small- and Medium- Sized Enterprises in Taiwan: An Analysis of Cases. Journal of Small Business Management, 36(4), 43-56.

McClelland, D. G. (1965). Need for achievement and entrepreneurship: A longitudinal study. Journal of Personality and Social Psychology, 1, 389-392.

McMillan, I. G., Siegel, R., \& SuhbaNarisimha, P. N. (1985). Criteria used by venture capitalists to evaluate new venture proposals. Journal of Business Venturing. Journal of Business Venturing, 1, 119-126.

Mitteness, C., Sudek, R., \& Cardon, M. S. (2012). Angel investor characteristics that determine whether perceived passion leads to higher evaluations of funding potential. Journal of Business Venturing, 27(5), 592-606.

Parker, S. C., \& van Praag, C. M. (2006). Schooling, Capital Constraints, and Entrepreneurial Performance. Journal of Business \& Economic Statistics, 24(4), 416-431.

Perry, J. T., Chandler, G. N., \& Markova, G. (2012). Entrepreneurial Effectuation: A Review and Suggestions for Future Research. Entrepreneurship Theory and Practice, 36(4), 837-861.

Peterson, R., Kozmetsky, G., \& Ridgway, N. (1983). Perceived causes of small business failures: a research note. ... Journal of Small Business, 8(1), 15-20. 
Pfeffer, J. (1993). Barriers To the Advance of Organizational Science: Paradigm Development As a Dependable Variable. Academy of Management Review, 18(4), 599-620.

Rauch, A., \& Frese, M. (2000). Psychological approaches to entrepreneurial success. A general model and an overview of findings. In C.L. Cooper \& I.T. Robertson (Eds.), International Review of Industrial and Organizational Psychology (pp. 101-142). Chichester: Wiley. Sma.

Rauch, A., Wiklund, J., Lumpkin, G. T., and Frese, M. (2009). Entrepreneurial orientation and business performance: An assessment of past research and suggestions for the future. Entrepreneurship : Theory and Practice, 33(3), 761-787.

Read, S., Dew, N., Sarasvathy, S. D., Song, M., \& Wiltbank, R. (2009). Marketing Under Uncertainty: The Logic of an Effectual Approach. Journal of Marketing, 73(3).

Sambasivan, M., Abdul, M., \& Yusop, Y. (2009). Impact of personal qualities and management skills of entrepreneurs on venture performance in Malaysia: Opportunity recognition skills as a mediating factor. Technovation, 29(11), 798-805. doi:10.1016/j. technovation.2009.04.002

Sarasvathy, S. (2001). Causation and effectuation: Toward a theoretical shift from economic inevitability to entrepreneurial contingency. Academy of Management Review, 26(2), 243-263.

Scheier, M. F., \& Carver, C. S. (1992). Effects of optimism on psychological and physical well-being: Theoretical overview and empirical update. Cognitive Therapy and Research, 16(2), 201-228.

Scheier, M. F., Carver, C. S., \& Bridges, M. W. (1994). Distinguishing Optimism from Nuerotism (and Trait Anxiety, self-Mastery, and Self- Esteem): A Reevaluation of Life Orientation Test. Journal of Personality and Social Psychology, 67(6), 1063-1078.

Shane, S., \& Venkataraman, S. (2000). The promise of entrepreneurship as a field of research. Academy of Management Review, 25(1), 217-226.

Sternberg, R., \& Wennekers, S. (2005). Determinants and Effects of New Business Creation Using Global Entrepreneurship Monitor Data. Small Business Economics, 24(3), 193-203.

Stigler, G. J. (1952). The Theory of Price. Macmillan, New York, NY. Survey Report (MSMEs) In Nigeria. (2010).

Timmons, J. A. (2000). New venture creation: Entrepreneurship 2000(5th ed.). Homewood, IL: Irwin.

Tokila, A., \& Tervo, H. (2010). Comparative advantage in self-employment and paid work. Can J Econ 27:273-289. The Annals of Regional Science, 47(3), 689-710.

Vallerand, R. J., Blanchard, C., Mageau, G. a, Koestner, R., Ratelle, C., Leonard, M., ... Marsolais, J. (2003). Les passions de l'ame: on obsessive and harmonious passion. Journal of Personality and Social Psychology, 85(4), 756-67.

Viale, R. (1992). Cognitive constraints of economic rationality. In: Simon, H. (Ed.), Economics, Bounded Rationality and the Cognitive Revolution. Edward Elgar Publishing Limited, Brookfield, VT, pp. 174-193.

Winborg, J., \& Landström, H. (2001). Financial bootstrapping in small businesses: Examining small business managers' resource acquisition behaviors. Journal of Business Venturing, 16, 235-254.

Zhao, L., \& Aram, J. D. (1995). Networking and growth of young technology-intensive ventures in China. Journal of Business Venturing, 10(95), 349-370. 